\title{
Differences in the feeding of Rhamdia quelen (Siluriformes, Heptapteridae) in four distinct lotic systems
}

\author{
Villares Junior, GA. ${ }^{a *}$ and Goitein R. ${ }^{a}$ \\ aDepartamento de Zoologia, Instituto de Biociências, Universidade Estadual Paulista - UNESP, \\ C.P. 199, CEP 13506-900, Av. 24-A, 1515, Rio Claro, SP, Brazil \\ *e-mail: villaresjunior@hotmail.com
}

Received: November 07, 2013 - Accepted: March 05, 2014 - Distributed: August 31, 2015

(With 1 figure)

\begin{abstract}
The aim of this study was to compare the food composition of Rhamdia quelen in four distinct order rivers. It was performed at a low part at the basin of the Sorocaba river in systems classified as first (Anastácio stream), second (Nego stream), fifth (Tatuí river) and sixth (Sorocaba river) orders. Collections were performed every month between January and December of 2011. The stomach contents were examined by using the alimentary index (IAi) and compared by the non-parametric method non-metric multidimensional scale ranking (NMDS) with the Spearman rank correlation. A diet difference was observed for individuals of the smaller systems (Anastácio and Nego streams) and the larger ones (Tatui and Sorocaba rivers), represented respectively by allochthonous and autochthonous organisms compounding their diets. Marginal vegetation and its interaction with the water conditions may respond to these composition differences.
\end{abstract}

Keywords: Sorocaba river basin, alochthonous items, autochthonous items, opportunist fish, Atlantic. Rain Forest.

\section{Diferenças na alimentação de Rhamdia quelen em quatro diferentes ordens de sistemas lóticos}

\begin{abstract}
Resumo
Este estudo teve como objetivo comparar a alimentação de Rhamdia quelen em quatro diferentes ordens de sistemas lóticos. O estudo foi realizado em um trecho da parte baixa da bacia do rio Sorocaba, em sistemas de primeira (Anastácio stream), segunda (Nego stream), quinta (Tatuí river) e sexta (Sorocaba river) ordens. As coletas foram realizadas mensalmente entre janeiro a dezembro de 2011. Os conteúdos estomacais foram analisados pelo índice alimentar (IAi) e comparados pelo método de escalonamento multidimencional não-metrico (NMDS), juntamente com a correlação de Spearman. Foi percebida uma diferença na dieta dos indivíduos dos sistemas menores, córregos Anastácio e Nego e os rios maiores, rios Tatuí e Sorocaba. Nos córregos Nego e Anastácio houve maior incidência de itens de origem alóctone na dieta, enquanto que nos rios Tatuí e Sorocaba foi observado o inverso. A diferença nos itens consumidos pode depender da ordem dos sistemas lóticos e da interação entre a vegetação marginal com o sistema aquático.
\end{abstract}

Palavras-chave: rio Sorocaba, itens alóctones, itens autóctones, oportunista, Mata Atlântica.

\section{Introduction}

The study of food utilization should play as an opportunity to add an interesting component to discuss theoretical aspects as reference to species replacement by spatial, temporal and trophic composition of niches (Schoener, 1974), and contributes to other purposes for the knowledge about the basic requirements of the species living in a certain community. It also helps for the comprehension about the trophic organization of one natural system and the quantitative evaluation related to biologic mechanisms intervening at the species interactions, such as predation, competition and other aspects (Esteves and Aranha, 1999).
The determination of the natural diet, as well as to get information about other aspects associated to feeding has been pointed out to be essential for the comprehension about the fish population ecology components, and also for the other organisms living within the community (Hahn et al., 1997). The acquisition of new data about food sources used by fishes can help for the understanding about their behavior (Hahn et al., 1997), and may furnish subsides for the construction of preservation theoretical bases or even for the foundations to create better structures to rearing of some species for economical purposes.

The family Heptateridae represents one of the largest radiations of neotropical catfishes and is composed by 
150 to 200 valid species, distributed from northern Argentina to southern Mexico (Bockmann and Guazzelli, 2003). Rhamdia quelen (Quoy and Gaimard, 1824) is distributed from southern Mexico to the River Plate, one of the most euritópicos neotropical fish, living in small streams, lakes and larger rivers, dwelling during day light under or beneath wood logs and rocks (Menezes et al., 2007). It seems to be more conspicuous in still waters (Barreto and Aranha, 2005). Its behavior suggests a benthonic way of life and a broad feeding spectrum, by feeding on terrestrial and aquatic insects, crustaceans, plants and fish (Casatti et al., 2001; Casatti and Castro, 2006). Its behavior suggests it to be an opportunistic benthonic predator, obtaining the food without revolving the substrate. According to Schulz and Leuchtenberger (2006), the individuals live more frequently at about 2 meters depth and uses to be more active during the morning and at late afternoon, avoiding temperatures under $18^{\circ} \mathrm{C}$.

Many references related to parameters about biological information to $R$. quelen are missing or are quite disperse at the specific literature (Gomes et al., 2000), as most of such references are directed to pisciculture and rearing under artificial situations (Gomiero et al., 2007), as the species is considered to be important for pounding in southern Brazil (Behr et al., 1999; Pereira et al., 2006). As references about the natural diet of the species are scarce, mainly by the fact that the species uses to live in many distinct habitats, the main goal of this study is to compare the food use of individuals in four distinct lotic systems. Comparisons were made among first, second, fifth and sixth order water streams.

\section{Material and Methods}

Fish and environmental data were obtained from the Sorocaba river basin, located in São Paulo State, in a subarea known as the superior medium Tietê. The main river within the system is the Sorocaba river and is recognized as part of the subsystem of the Tietê river basin (Smith et al., 2003; Villares Junior and Goitein, 2006; Villares Junior et al., 2011). Three important tributaries flow to the Sorocaba river: The Sarapuí, Tatuí and Guarapó rivers. Some other smaller streams and marginal lagoons contribute to the enlargement of the environmental variability (Villares Junior and Goitein, 2006).

The sampling sites are located in four distinct order streams: Anastácio (first order; $23^{\circ} 19^{\prime} 57^{\prime \prime} \mathrm{S}$ and $47^{\circ} 47^{\prime} 07^{\prime \prime} \mathrm{W}$ ), Nego (second order; $23^{\circ} 19^{\prime} 52^{\prime \prime} \mathrm{S}$ and $47^{\circ} 466^{\prime} 50^{\prime \prime} \mathrm{W}$ ), Tatuí (fifth order; $23^{\circ} 19^{\prime} 43^{\prime \prime} \mathrm{S}$ and $47^{\circ} 46^{\prime} 46^{\prime \prime} \mathrm{W}$ ) and Sorocaba (sixth order; $23^{\circ} 19^{\prime} 09^{\prime \prime} \mathrm{S} 47^{\circ} 46^{\prime} 45^{\prime \prime} \mathrm{W}$ ).

The Anastácio stream`s width is less than one meter and its mean depth hardly attains one meter. Nego stream is a little wider, as it may reach 2 meters, while its mean depth varies between 1,5 and $2 \mathrm{~m}$. Tatuí river flows to the Sorocaba river and attaining at its lower place about 10 and 20 meters with a depth varying between 1 and 3 meters. The Sorocaba river width is quite larger and its width goes to 30 to 50 meters, and depth between 1 and 6 meters.
(Villares Junior and Goitein, 2006; Villares Junior, 2011). The marginal vegetation is relatively in a good preservation state at the study sites.

The sampling devices were used according to the characteristic of the water environmental dimensions. In the Tatuí and Sorocaba rivers, fish were caught using distinct gill nets, whose meshes between opposite knots measured 3,$0 ; 4,0 ; 5,0 \mathrm{~cm}$. At the Nego and Anastacio streams traps and sieves were used as the dimensions limit collections to such devices. Samples were collected every month from January to December 2012. So, 12 samplings were made. Such samples were gathered separately for each of the three sites, and totalized 12 samplings. The fishing effort was performed in a $75 \mathrm{~m}^{2}$ area covered with gill nets and ten traps. After these activities fish were transported in ice for posterior freezing until handling.

The stomach contents named food items were identified until the least possible taxonomic level and analyzed using the alimentary index (IAi) proposed by Kawakami and Vazzoler (1980). This index is calculated using the expression $\mathrm{IA} i=[\mathrm{Fi} \times \mathrm{Vi} / \Sigma(\mathrm{Fi} \times \mathrm{Vi})] \mathrm{x} 100$, where $\mathrm{i}=$ feeding item, $\mathrm{Fi}=$ frequency of occurrence $(\%)$ and $\mathrm{Vi}=$ item volume $(\%)$. Food items were observed and identified by using an stereomicroscope.

The IAi data were analyzed by utilizing a non-parametric non-metric multidimensional scale ranking (NMDS) with Bray-Curtis similarity matrixes (Clark and Warwick, 2001) to analyze the food items similarity and among the four sites. The comparison statistical analysis was performed among three sites using Spearman`s rank correlation (5\%) (Fritz, 1974). The statistical analyses were performed using PAST 2.15 Software (Hammer et al., 2001).

\section{Results}

The specimens of Rhamdia quelen were collecte in a number of 193 individuals, from which 32 were in Nego stream, 22 in Anastácio stream, 68 in the Tatuí river and 71 in Sorocaba river. The stomach analysis showed the diet of $R$. quelen to be composed by a diversity of food items (17 distinct items), both from autochthonous and allochthonous origin (as show in Table 1).

According to the IAi analyses a distinction for the diet composition of individuals from the Anastácio and Nego streams and the larger water systems can be perceived (Figure 1). The smaller stream individuals feed more on alloctonous items, whereas those from the larger rivers use more autochthonous items as food. The Spearman correlation analysis $(5 \%)$ indicated the existence of a strong correlation between the Anastácio and Nego streams and between the Tatuí and Sorocaba rivers (as show in Table 2).

\section{Discussion}

The analysis about feeding of $R$. quelen at the distinct lotic studied systems has shown a marked difference between the individuals of the smaller systems and those of the larger ones. In all the places where the study was performed there is riparian vegetation in preserved 
Table 1. Alimentary índex (IAi) values of Ramdia quelen in Nego and Anastácio streams, and Tatuí and Sorocaba rivers.

\begin{tabular}{ccccc}
\hline Alimentary item & Anastácio stream & Nego stream & Tatuí river & Sorocaba river \\
\hline Autochthonous item & & & & \\
Fish & 3.30 & 2.20 & 39.60 & 76.00 \\
Diptera immature & 12.50 & 14.60 & 12.40 & 5.70 \\
Decapoda & - & - & - & 0.50 \\
Mollusca & - & - & - & 2.00 \\
Odonata immature & 0.30 & - & 0.60 & 0.20 \\
Allochthonous item & & & & \\
Diptera adult & 4.60 & 6.10 & 0.50 & 0.50 \\
Orthoptera & 8.40 & 5.70 & 0.30 & 0.20 \\
Plant & 7.10 & 11.20 & 2.30 & 3.10 \\
Hymenoptera & 18.50 & 13.30 & 2.30 & 1.20 \\
Blattaria & 6.00 & 5.70 & - & 0.20 \\
Oligochaeta & 15.40 & 7.50 & 32.20 & 7.20 \\
Coleoptera & 9.70 & 11.20 & 0.70 & 0.30 \\
Aranae & 0.20 & 1.50 & 0.60 & 0.10 \\
Isopoda & 0.20 & 0,40 & 0.20 & - \\
Hemiptera & 3.60 & 4.50 & 0.30 & - \\
Lepdoptera & 6.20 & 6,00 & - & - \\
Sediment/Detritus & 2.00 & 10.52 & 1.60 & 2.50 \\
\hline
\end{tabular}
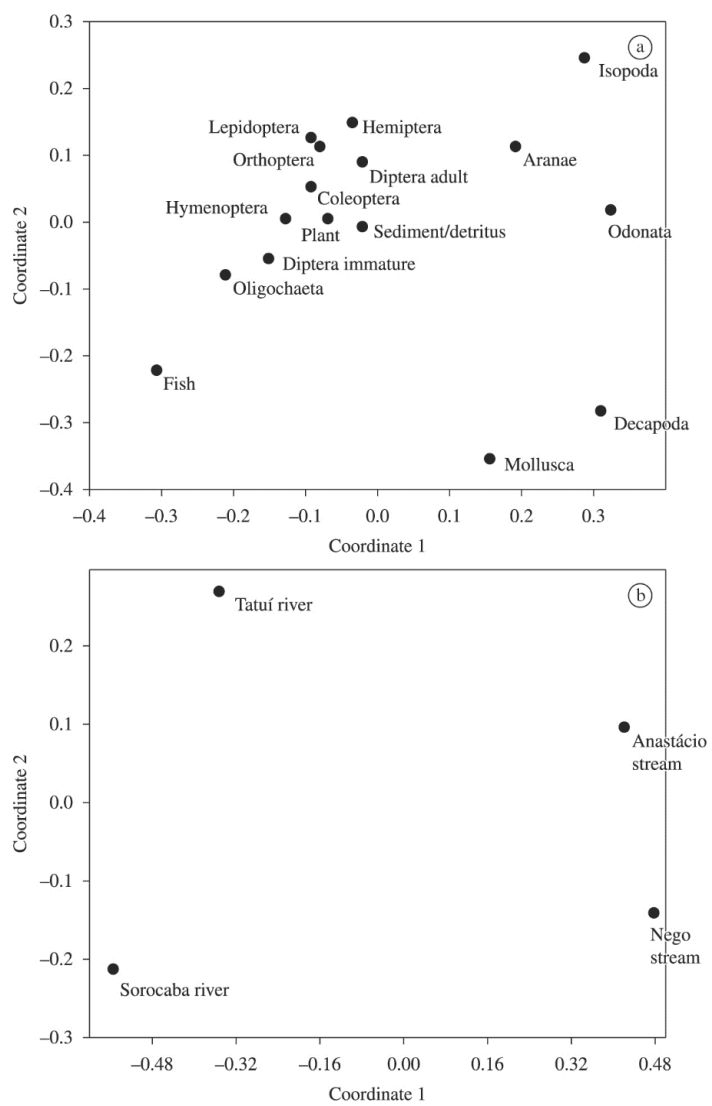

Figure 1. Graphic representation of the non metric multidimensional scaling analysis (NMDS) of the diet of Rhamdia quelen: (a) alimentary itens, (b) collection sites.
Table 2. Statistical comparison (Spearman rank correlations) of alimentary index (IAi) of Rhamdia quelen between sites of study. The significant correlations coefficients (rs) $(\mathrm{p}<0.01)$ are highlighted in bold.

\begin{tabular}{cccc}
\hline & $\begin{array}{c}\text { Sorocaba } \\
\text { river }\end{array}$ & Tatuí river & $\begin{array}{c}\text { Nego } \\
\text { stream }\end{array}$ \\
\hline Tatuí river & $\mathbf{0 . 6 9 8 7}$ & - & - \\
Nego stream & 0.3945 & 0.5722 & - \\
Anastácio & 0.0278 & 0.5126 & $\mathbf{0 . 8 5 4 7}$ \\
stream & & & \\
\hline
\end{tabular}

situation. If a direct influence of the neighbor vegetation may have an influence, as such conditions may play an important role for aquatic systems and their inhabitants, and this interface between both systems can be intensified (Barrela et al., 2001; Rezende and Mazzoni, 2005). At the smaller streams the vegetation bends completely over the water, and this is called as riparian vegetation. Alloctonous organisms may be more frequently furnished to the aquatic system, and this was confirmed by the presence of arthropods and terrestrial vegetation.

Some studies concerning lotic systems of low order pointed the conspicuous presence of items for $R$. quelen whose origin is from the outside. Gomiero et al. (2007) has identified 19 food items in two rivers of the Atlantic forest presenting a higher importance within the stomach contents of this species and some vegetal material, suggesting its diet to be omnivorous, but predominantly carnivorous. Casatti (2002), by studying this species in a first order stream (São Carlos Stream) registered a high consummation of Araneae, Hymenoptera, some vegetal and Trichoptera and 
On the other hand, in larger aquatic systems the species uses to consume in a higher importance autochthonous items. Brasil-Sousa et al. (2009) found in a $6^{\text {th }}$ order river (Macaé river) a consume based predominantly on autochthonous items, mainly formed by crustaceans and fish, and defined $R$. quelen as a carnivorous species specialized for crustaceans and fish in higher amount, followed by other items in a lesser importance ( 53 items).

The elevated incidence of fish remnants within the stomach contents seems to confirm such a tendency of food intake by the species in this stucy as also happened at the Corumbá reservoir (GO) (Luz-Agostinho et al., 2006), the same being confirmed by Gomes et al. (2000) by characterizing the species as omnivorous but highly piscivorous.

The autochthonous origin of the food items when $R$. quelen lives is larger systems seems to represent a lesser influence of the marginal vegetation and may suggest the species to display an opportunistic behavior, but in any case the marginal vegetation may play an influence by furnishing resources to the autochthonous organisms found within the stomach contents of $R$. quelen (Alvin and Peret, 2004).

The presence of a riparian forest, such as flooding pulses may be essential for the production and transportation of nutrients to the freshwater fishes (Agostinho and Zalewski, 1995) and other aquatic organisms, meaning that rivers are never auto-sufficient, and so depending on the external resources. Some food items have been abundant in all the analyzed systems, and insects during their immature stages (Chironomidae larvae and pupae) use to be the main consumed invertebrate and are in some way also dependent on the external resources (Alvin and Peret, 2004). An important parameter of the external (terrestrial) influence to maintain the fish an general water community may be represented by the continuous entrance of the organic matter to the aquatic system, in a clear difference to what happens to the sea (Corbisier et al., 2006), as a food resource to the autochthonous organism living in the rivers, as the aquatic insects also depend on the flooding situations when such resources are incorporated to the aquatic medium. (Walker et al., 1990). Aquatic insects are important items in the diet of fish found in flood plains (Hahn et al., 1997) and its wide distribution in water bodies allows the capture of different species of neotropical fishes (Alvin and Peret, 2004). This is also stated by Vidotto-Magnoni and Carvalho (2009) who observed Odonata nymphs and Chironomidae pupae as the main food resource for $R$. quelen at the Nova Avanhandava reservoir to which fish small crustaceans and vegetal material should represent only a complementary food.

The food availability has been considered as a primordial factor to characterize the kind of items representing the feeding of freshwater fishes, who may be seen as the ways by which on may see what is the most abundant food resource in the water medium (Kahilainen and Lehtonem, 2003). So, it may be difficult to classify the species other to a generalist feeder (Brasil-Sousa et al., 2009).
Such a plasticity may be an expected fact, as the normal instability of the freshwater systems may preserve the species which have developed a means of survival within such lotic systems by adapting to distinct food resources (Lowe-McConnell, 1999), a commonly observed fact among the neotropical fishes (Gerking, 1994).

In this context we can say that $R$. quelen behaves as an opportunistic species that exploits the resources available at the environment and the intensity of consumption of food items of allochthonous and autochthonous origin may depend on the order of lotic systems and the kind of interaction between the marginal vegetation and the water system, and it consists mainly by allochthonous items to the diet of fishes in environments of lower order and autochthonous items in those living in larger environments.

\section{Acknowledgements}

We thank to the friends whose help was very important: André Teixeira da Silva, Leandro Müller Gomiero, Mauricio Cetra and Maria M. Aparecida. We also thank to the Chico Mendes Institute (SISBIO) for the authorization for fish collections.

\section{References}

AGOSTINHO, AA. and ZALEWSKI, M., 1995. The dependence of fish community structure and dynamics on floodplain and riparian ecotone zone in Paraná River, Brazil. Hydrobiologia, vol. 303, no. 1-3, p. 141-148. http://dx.doi.org/10.1007/BF00034051.

ALVIN, M C.C. and PERET, A.C., 2004. Food resources sustaining the fish fauna in a section ot the upper São Francisco River in Três Marias, MG, Brazil. Revista Brasileira de Biologia = Brazilian Journal of Biology, vol. 64, no. 2, p. 195-202.

BARRELA, W., PETRERE-JÚNIOR, M., SMITH, WS. and MONTAG, LF., 2001. As relações entre as matas ciliares, os rios e os peixes. In RODRIGUES, R.R. and LEITÃO-FILHO, HF. Matas ciliares: conservação e recuperação. São Paulo: EDUSP. p. 187-207.

BARRETO, AP. and ARANHA, LMR., 2005. Assembleia de peixes de um riacho da Floresta Atlântica: composição e distribuição espacial (Guaraqueçaba, Paraná, Brasil). Acta Scientiarum, vol. 27 , no. 2, p. 153-160.

BEHR, ER., RADÜNZ NETO, J., TRONCO, AP. and FONTANA, AP., 1999. Influência de diferentes níveis de luminosidade sobre o desenvolvimento de larvas de Jundiá (Rhamdia quelen) (Quoy \& Gaimard, 1824)(Pisces: pimelodidae). Acta Scientiarum, vol. 21, no. 2, p. 235-330.

BOCKMANN, F. and GUAZZELLI, AYGM., 2003. Heptapteridae. In REIS, R.E., KULLANDER, S.O. and FERRARIS, CJ. Check list of the freshwater fishes of South and Central America. Porto Alegre: EDIPUCRS. p. 406-431.

BRASIL-SOUSA, C., MARQUES, RM. and ALBRECHT, MP., 2009. Segregação alimentar entre duas espécies de Heptapteridae no rio Macaé, RJ. Biota Neotropica, vol. 9, no. 3, p. 31-37.

CASATTI, L. and CASTRO, RMC., 2006. Testing the ecomorphological hypothesis in a headwater riffles fish assemblage of the rio São 
Francisco southeastern Brazil. Neotropical Ichthyology, vol. 4, no. 2, p. 203-214. http://dx.doi.org/10.1590/S1679-62252006000200006.

CASATTI, L., 2002. Alimentação dos peixes em um riacho do Parque Estadual Morro do Diabo, bacia do alto rio Paraná, sudeste do Brasil. Biota Neotropica, vol. 2, no. 2, p. 1-14. http://dx.doi. org/10.1590/S1676-06032002000200012.

CASATTI, L., LANGEANI, F. and CASTRO, RMC., 2001. Peixes de riacho do Parque Estadual Morro do Diabo, bacia do alto rio Paraná, SP. Biota Neotropica, vol. 1, no. 1-2, p. 1-15. http://dx.doi.org/10.1590/S1676-06032001000100005.

CLARK, KR. and WARWICK, RM., 2001. Change in marine communities: an approach to statistical and interpretation. Plymouth: Plymouth Marine Laboratory. 859 p.

CORBISIER, TN., SOARES, LSH., PETTI, MAV., MUTO, EY., SILVA, MHC., MCCLELLAND, J. and VALIELA, I., 2006. Use of isotopic signature to assess the food web in the tropical shallow marine ecosystem of Southeastern Brazil. Aquatic Ecology, vol. 40, no. 3, p. 381-390. http://dx.doi.org/10.1007/s10452-006-9033-7.

ESTEVES, KE. and ARANHA, JMR., 1999. Ecologia trófica de peixes de riachos. In CARAMASCHI, E.P., MAZZONI, R. and PERES-NETO, PR. (Eds.). Ecologia de peixes de Riacho. Rio de Janeiro: PPGE/UFRJ. p. 157-182. Série Oecologia Brasiliensis, vol. 6 .

FRITZ, ES., 1974. Total diet comparison in fishes by spearman rank correlation coeficients. Copeia, vol. 1, no. 1, p. 210-214. http://dx.doi.org/10.2307/1443025.

GERKING, SD., 1994. Feeding ecology of fish. California: Academic Press. 416 p.

GOMES, LC., GOLOMBIESKII, JL., GOMES, ARC. and BALDISSEROTTO, B., 2000. Biologia do Jundiá Rhamdia quelen (Teleostei, Pimelodidae). Ciência Rural, vol. 30, no. 1, p. 179-185. http://dx.doi.org/10.1590/S0103-84782000000100029.

GOMIERO, LM., SOUZA, UP. and BRAGA, FMS., 2007. Reprodução e alimentação de Rhamdia quelen (Quoy \& Gaimard, 1824) em rios do Núcleo Santa Virginia, Parque estadual da Serra do Mar, São Paulo, SP. Biota Neotropica, vol. 7, no. 3, p. 127-133. http://dx.doi.org/10.1590/S1676-06032007000300015.

HAHN, NS., ANDRIAN, IF., FUGI, R. and ALMEIDA, VLL., 1997. Ecologia trófica. In VAZZOLER, A.E.A.M., AGOSTINHO, A.A. and HAHN, N.S. (Eds). A planície de inundação do alto rio Paraná: aspectos físicos, biológicos e socioeconômicos. Maringá: EDUEM. p. 209-228.

HAMMER, Ø., HARPER, D A.T. and RYAN, P.D., 2001. PAST: Paleontological Statistics Software Package for education and data analysis. Palaeontologia Electronica, vol. 4, no. 1, p. 1-9. Available from: http://palaeo-electronica.org/2001_1/past/ issue1_01.htm. Access in: 10 Oct. 2013.

KAHILAINEN, K. and LEHTONEM, H., 2003. Piscivory and prey selection of four predator species in a whitefish dominated subarctic lake. Journal of Fish Biology, vol. 63, no. 3, p. 659-672. http://dx.doi.org/10.1046/j.1095-8649.2003.00179.x.

KAWAKAMI, E. and VAZZOLER, G., 1980. Método gráfico e estimativa de índice alimentar aplicado no estudo de alimentação de peixes. Boletim do Instituto Oceanográfico, vol. 29, no. 2, p. 205-207. http://dx.doi.org/10.1590/S0373-55241980000200043.
LOWE-MCCONNELL, RHL., 1999. Estudos ecológicos de comunidades de peixes tropicais. São Paulo: EDUSP. 535 p.

LUZ-AGOSTINHO, KDG., BINI, LM., FUGI, R., AGOSTINHO, AA. and JULIO JÚNIOR, HF., 2006. Food spectrum and trophic structure of the ichthyofauna of Corumbá reservoir, Paraná river basin, Brazil. Neotropical Ichthyology, vol. 4, no. 1, p. 61-68. http://dx.doi.org/10.1590/S1679-62252006000100005.

MENEZES, NA., WEITZMAN, SH., OYAKAWA, OT., LIMA, FCT., CASTRO, R M.C. and WEITZMAN, M.J., 2007. Peixes de água doce da Mata Atlântica. Lista preliminar das espécies e comentários sobre conservação de peixes de água doce neotropicais. São Paulo: MZUSP. 408 p.

PEREIRA, CR., BARCELLOS, LJG., KREUTZ, LC., QUEVEDO, RM., RITTER, F. and SILVA, LB., 2006. Embryonic and larval development of Jundiá (Rhamdia quelen, Quoy and Gaimard, 1824, Pisces, TeleosteI), a South American catfish. Revista Brasileira de Biologia $=$ Brazilian Journal of Biology, vol. 66, no. 4, p. 1057-1063. http://dx.doi.org/10.1590/S1519-69842006000600013. PMid:17299942.

REZENDE, CF. and MAZZONI, R., 2005. Seasonal variation in the input of allochthnous matter in an Atlantic Rain Forest stream, Ilha Grande-RJ. Acta Limnologica Brasiliensia, vol. 17, no. 2, p. 167-172.

SCHOENER, TW., 1974. Resource partitioning in ecological communities. Science, vol. 185, no. 4145, p. 27-39. http://dx.doi. org/10.1126/science.185.4145.27. PMid:17779277.

SCHULZ, UH. and LEUCHTENBERGER, C., 2006. Activity patterns of South American silver catfish (Rhamdia quelen). Revista Brasileira de Biologia = Brazilian Journal of Biology, vol. 66, no. 2A, p. 565-574. http://dx.doi.org/10.1590/S151969842006000300024 . PMid:16862313.

SMITH, WS., PETRERE JÚNIOR, M. and BARRELLA, W., 2003. The fish fauna in tropical rivers: the case of the Sorocaba River basin, São Paulo, Brazil. Revista de Biologia Tropical, vol. 51, no. 3-4, p. 769-782. PMid:15162785.

VIDOTTO-MAGNONI, AP. and CARVALHO, ED., 2009. Aquatic insects as the main food resource of community in a Neotropical reservoir. Neotropical Ichthyology, vol. 7, no. 4, p. 701-708. http://dx.doi.org/10.1590/S1679-62252009000400020.

VILLARES JUNIOR, GA. and GOITEIN, R., 2006. Fish, Sorocaba basin, São Paulo State, Brazil. Check List, vol. 2, no. 3, p. 68-73. http://dx.doi.org/10.15560/2.3.68.

VILLARES JUNIOR, GA., 2011. Fish, Tatuí river basin, state of São Paulo, Brazil. Check List, vol. 7, no. 3, p. 287-289.

VILLARES JUNIOR, GA., GOMIERO, LM. and GOITEIN, R., 2011. Biological aspects of Schizodon nasutus Kner, 1858 (Characiformes, Anostomidae) in the low Sorocaba river basin, São Paulo state, Brazil. Revista Brasileira de Biologia = Brazilian Journal of Biology, vol. 71, no. 3, p. 763-770. http://dx.doi. org/10.1590/S1519-69842011000400023. PMid:21881802.

WALKER, I., HENDERSON, P. and STERRY, P., 1990. On the patterns of biomass transfer in the benthic fauna of an Amazonian blackwater river, as evidenced by P32 label experiment. Hydrobiologia, vol. 12, p. 23-34. 